
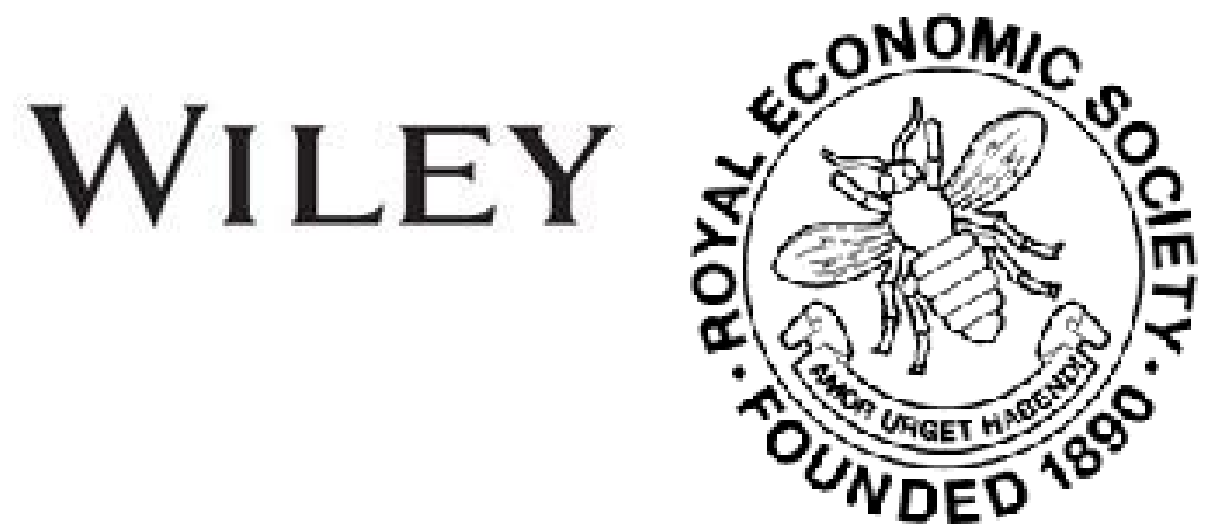

\title{
Australia Under Protection
}

Author(s): Matthew Macfie

Source: The Economic Journal, Vol. 3, No. 10 (Jun., 1893), pp. 297-307

Published by: Wiley on behalf of the Royal Economic Society

Stable URL: http://www.jstor.org/stable/2955674

Accessed: 26-04-2016 22:35 UTC

Your use of the JSTOR archive indicates your acceptance of the Terms \& Conditions of Use, available at

http://about.jstor.org/terms

JSTOR is a not-for-profit service that helps scholars, researchers, and students discover, use, and build upon a wide range of content in a trusted digital archive. We use information technology and tools to increase productivity and facilitate new forms of scholarship. For more information about JSTOR, please contact support@jstor.org.

Wiley, Royal Economic Society are collaborating with JSTOR to digitize, preserve and extend access to The Economic Journal 
for which holders of the shares are liable and this again will widen and solidify the share basis. Numbers of Australian shareholders, just now, are unable to pay a penny in liquidation of their liability for uncalled capital and the process is made as easy for them as possible, in the schemes of reconstruction, by spreading calls over long periods. It is only to be hoped for the sake of the credit of all Australian institutions, that no measures will be passed by the Colonial Parliaments to mitigate that liability. Enough damage has been done already by interference from above.

ARthur Ellis.

\section{Australia under Protection.}

Protection to native industries is a cardinal dogma in the political creed of the great majority of the working elasses in Australia. By this feature they are mainly to be distinguished from the English type of the order to which they belong. Manhood suffrage combined with the compact organisation of labour which is in progress has already placed the fiscal and political destinies of Australasia in their hands. At the last General Election in Victoria more than double their number who had seats in the preceding Parliament were successful candidates ; and when the present Legislative Assembly in New South Wales was chosen it was found that one-third of the members were direct representatives of labour. As might be expected, these men are always able to turn the scale in a Parliamentary division against those opposed to the interests of their class. The latter fact is the only explanation of the Dibbs Government in Sydney, so soon after their accession to office, following in the wake of Victoria by introducing protection for the first time in the history of the parent Colony. The set of the tide is in the direction of restricting imports throughout the whole of Australasia, the Trades Union agitators being quite unanimous in their fiscal views.

As Victoria has enjoyed for a longer period than any other Australasian Colony the opportunity of testing by practical experience the merits of protection-having adopted the system upwards of a quarter of a century ago-it may be convenient to glance at the actual results. It is often remarked with oracular assurance by the local protectionist politicians and journalists that economic methods suited to the requirements of an old country might prove ruinous in a new one. They quote John Stuart Mill as favouring the continuance of protection in a young community so long as may be necessary to develop its industries to maturity and supply all local manufacturing wants which can possibly be met from internal sources. But the influence of protection in Victoria on the growth of infant industries, on the distribution of population, on the proportion of exports to imports, on the cost of articles of consumption, and on the purchasing power of money gives an unqualified contradiction to Mill's theory, despite the 
apparently rapid and, until recently, apparently solid expansion of that Colony. A close study of the factors concerned in producing the semblance of prosperity in Victoria, which, for a time, was mistaken for reality, leads irresistibly to the conclusion that the marked activity witnessed, at intervals, in Colonial banking, Stock Exchange speculation, land booms, building manias, and manufactures had no more to do with protection as its cause than Tenterden steeple has to do with producing Goodwin sands. The reckoning of protectionists conveniently ignores the fact that $£ 230,000,000$ has been dug out of Victorian mines, that $£ 44,000,000$ of Government borrowings has been spent on public works in the Colony, that the latter sum has been supplemented by an addition of $£ 17,000,000$ - chiefly from England,invested in private enterprises, that over $£ 3,000,000$ in wool is exported annually, that considerable returns are derived from the export of cereals, dairy produce, and general inter-Colonial trade, and that the larger part of $£ 7,500,000$ - the yearly Government income-is put in circulation within the Colony.

The origin of protection in Victoria is more easily described than defended. A few years after the discovery of gold in the Bendigo and Ballarat districts the alluvial diggings showed signs of approaching exhaustion. Auriferous reefs, in every case, needed a larger amount of capital to work them than ordinary diggers could command. The bulk of those who had courted fortune in surface mining had been brought up to some handicraft in the United Kingdom or Continental Europe ; and failure in the hunt for gold meant for them the loss of their all. Some of them tried farming before their available means had come to an end. Those of a versatile turn who entered on this pursuit and were possessed of sufficient industry and patience thrived on the soil beyond their anticipations. A still larger number who lacked these qualities, however, failed. In the six years immediately following 1856 the total number engaged in gold mining in the Colony dwindled to small proportions. The burning question of the hour then began to engage earnest attention: Could regular work be provided for the unlucky ones by founding, as widely as possible, the skilled industries to which they had been trained in the countries from which they had emigrated? This question was warmly discussed in and out of Parliament for an entire decade, and divided the Colonists into two opposing camps, the more intelligent classes being uniformly free traders. The less educated majority were gradually won over to protection by demagogues who unceasingly preached the advent of a working man's millennium to believers in their fiscal panacea. The sceptical minority, on the other hand, predicted that a protective tariff would have the effect of ruining Colonial commerce without placing manufactures on a basis satisfactory either to employers or wageearners. Unscrupulous Cleons, ever ready to flatter Demos and praise his errors as a short cut to their own political and financial advantage, at length succeeded in working up a majority in the people's Chamber 
in favour of the restriction of imports as 'the settled policy of the country.' Import merchants in Melbourne, however, formed a freetrade league with the object of bringing pressure to bear on the Legislative Council for the rejection of the proposed tariff measure. But the upper House, composed mostly of free traders, after having several times thrown out the bill, at length felt reluctantly compelled to surrender to the popular will. At the same time it is but fair to state that some advocates of the restrictive system in the Assembly supported it as a mere tentative expedient for temporarily nursing ' infant industries' on the understanding that it should be given up when they were able to hold their own without artificial aid. These well-meaning novices had yet to learn, what has since been amply confirmed by events, that once a protective tariff is conceded by a Legislature, no bounds can be set to the demands of its supporters for increased prohibitory duties.

The first protectionist tariff became law in Victoria in 1865 and remained unaltered for six years-an interval long enough, it might be supposed, to test its efficacy or, at least, to indicate its tendency. Yet no additional inquiry for labour could be traced to its influence, and to no perceptible extent had the volume of foreign imports been diminished by it. So far from the prohibitive tariff, at the end of the above-named period, having fostered any infant industry to a selfsupporting condition, or having served the temporary purpose for which alone it was understood in some quarters to have been imposed, the results were quite the other way. Mr. (now Sir) Graham Berry, who was Colonial Treasurer in 1871, finding the industries so anxiously cared for by him too weak to progress unaided, resolved to afford them still more protection. Accordingly an addition of 10 per cent. was made to the duties already in force, and an equal impost was put on many articles which up to that time had been free. When Mr. Berry again became official head of the Treasury, six years later, in 1878, the industries for whose emergence from babyhood he had so long and anxiously laboured were still to be seen in their former state of infantile feebleness. But although the proof was overwhelming that protection was utterly powerless to foster them to independence of State aid, Mr. Berry swept into his protectionist net every import which had escaped his prohibitory tariff in 1871, while duties which had previously existed were increased. ${ }^{1}$ Indeed, so recently as June, 1892, the mischievous results of the system were further exemplified under the agency of the same gentleman in a yet more remarkable manner. At that date Sir Graham Berry, who was once more Treasurer of Victoria in the late Shiels Ministry, proposed and carried fresh taxes in the Legislative Assembly. This course was deemed necessary by the avowed impossibility of the Colonial Government continuing to meet the half-yearly interest on their heavy indebtedness to British lenders without creating new sources of

1 Victoria and its Metropolis (McCarron, Bird, and Co.), p. 417. 
taxation. But the idea of cutting down the disproportionately large salaries of the Governor, the Ministers, the members of the lower House, the Agent-General, and other highly-paid functionaries does not seem to have occurred to him. A great part of the late Treasurer's former taxation increased the cost of clothing, furniture, and other manufactures to the people, who belong chiefly to the working classes. Under his most recent turn of the fiscal screw the food of the majority is still more heavily taxed, the new burdens, like the old ones, being felt most severely by the poor. Great irritation has been caused by the augmented stock import tax to farmers in New South Wales and Queensland sending sheep and cattle into Victoria. Cattle are now taxed $30 s$. per head, sheep $2 s$, and horses $50 s$. per head. A duty of $7 s$. per $100 \mathrm{lbs}$. of beef and mutton and of $10 \mathrm{~s}$. per $100 \mathrm{lbs}$. of pork has also been passed. These new and excessive imposts were voted by seventy against seventeen votes in the people's Chamber of Victoria. An Oxford man resident in the Colony has not inaptly parodied as follows the well-known lines in the 'Devil's Walk' by Porson, to express his contempt for the political ignorance which perpetuates protection in Victoria, despite the evils it inflicts on the community :-

' Down the river did glide with wind and with tide, A pig with great celerity,

And the devil grinn'd, as he saw with a smile

That it cut its own throat,- -and he thought all the while Of Victoria's protective prosperity!'

A few instances may be cited of the actual working of the protective tariff in raising the prices of protected articles to consumers without enlarging the area of remunerative employment to labour. Nailmaking is a protected trade whose growth has not been in proportion to the high tariff by which it is protected. A few years ago there were two factories in Victoria engaged in this industry, employing nine men and six boys. The duty on imported horse nails for the encouragement of the native production of these articles was $£ 12$ per ton, and on other kinds of nails it was $£ 3$ per ton. In 1889 another factory was started but remained unsuccessful until the duty on descriptions other than horse nails was raised from $£ 3$ to $£ 5$, when the proprietor began to make profits. A fourth factory was established on the report of the industry having become financially successful. According to the latest accounts the total number of hands now occupied in this branch is eighteen men and twelve boys. The annual production by these employees is only 1000 tons of wire nails, and about 200 tons of other sorts of nails. For the privilege of maintaining a mere handful of men and boys carrying on this particular industry local consumers have to pay no less than $£ 26,722$ a year beyond what nails would cost them if there were no protective duties. This amount includes the duty actually paid in a recent year on imported nails, which very largely exceeded in amount those manufactured in the Colony, notwithstand- 
ing the high tariff by which the native article was protected. If this extra cost upon the amount of nails of Victorian manufacture and the quantity imported which is due to protection be divided by the eighteen men and twelve boys, for supporting whom the duty is expressly levied, it will be found equivalent to paying for each hand nearly $£ 900$ per annum! But it usually happens in protected countries that the working man has to be content with less than a tithe of that rate of remuneration, the remaining ninetenths going into the pockets of his employers and a few importers. A similar story might be told, with variations, of other protected Colonial industries.

The revenue from customs duties before the occurrence of the existing trade depression in the Colony amounted to $£ 2,879,830$. This sum the inhabitants were compelled to pay, directly, for permission to exchange the products of their labour for commodities which they desired to import from the outside world. Those engaged in the business of importing of course paid the amount exacted by the customs in the first instance. ' It is needful to bear in mind, for the purposes of the present estimate, that there are two profits, and sometimes three, after goods imported land in the Colony and before they reach the retail customer. We are well within the mark in reckoning the profit of the importer at 20 per cent. and that of the retailer at $33 \frac{1}{3}$ per cent. $£ 100$ in duty paid by the importer would thus be charged to the retailer at $£ 120$ and by the latter to the consumer at $£ 160$. According to this calculation $£ 2,879,830$ originally paid in duty, and refunded by consumers, with the profits of the importer and the retailer charged on the duty, alone would amount to $£ 4,607,728$. To this direct cost of protective duties, with the profits of middle men calculated upon them, must be added a percentage equal to the higher prices of protected manufactures produced in Victoria, which would have been turned out of the local factories or imported into the Colony at lower prices had there been no protective tariff. There must also be included the profit of the middleman on the latter estimated excess of price. The amount representing this further advance has been put at $£ 2,500,000$, as approximately correct. But to be perfectly safe we can reduce it to $£ 2,000,000$. Adding this to $£ 4,607,728-$ the amount of the customs duties and the profits of importers and retailers on these duties which are paid by consumers--we arrive at the direct ascertainable cost of protection to the population of Victoria, which is no less than $£ 6,607,728$ per annum. There is still, however, excluded from the reckoning a probably larger indirect loss due to the influence of protection in diverting production from more profitable industries on the soil to those less profitable in the towns. But of this I purposely refrain from taking any account in figures, that protectionists may have whatever advantage there is in an extremely moderate statement of facts. The total estimated population of Victoria in recent years, with which this calculation is concerned, was $1,118,077$. If the large financial burden imposed on the Victorian 
people by the protective system be divided by their numbers, it will be found that the cost of protective duties levied per head of the inhabitants amounts to $£ 518 \mathrm{~s}$. per annum. This means that every father of a family of four children in the Colony has to pay $£ 358 s$. per annum out of his earnings in order to maintain protection. By a strange infatuation the working classes of Victoria ignore the fact that this heavy impost is paid for the most part by themselves. ${ }^{1}$ They seem to imagine that it is borne by people of a wealthier class- 50,000 landowners and other capitalists-whom they euphemistically classify under the title of 'the consumer.' It must not be forgotten that, included in the above estimate of the cost of protection to consumers, is the amount necessary for carrying on the public services of the Colony, which, in the absence of protection, would be derived from taxes raised for purely revenue purposes. But my contention is that had the same effort been made to develop the immense resources of the soil which has been directed to building up by high tariffs town industries, the aggregate wealth of the country would have been enormously increased. Out of the augmented fund of Colonial wealth created by the culture of natural products for which there is a profitable market in Europe, the taxpayers could have more easily borne the amount levied for revenue out of an income and a land tax, than they can now bear the oppressive burdens cast upon them by protection.

What consideration does each head of a family of four get in return for this compulsory payment of $£ 358 s$. abstracted from his scanty earnings? The working classes of Victoria number about 56,000. The hands similarly employed in the factories and workshops of New South Wales were fewer by about 10,000 than those in Victoria before protection was introduced into the parent Colony by the present (Dibbs) Government. It may be assumed, therefore, that the latter number would represent the men, women, and children in Victoria who are especially indebted to protection for employment, as 46,000 workpeople were employed in the sister Colony under the régime of free trade. It is interesting to know what tax per head the employment of these privileged 10,000 persons entails upon the Victorian population as a whole. It was shown above, that $£ 6,607,728$ is roughly the direct cost of protection to Victoria, and it has been ascertained that in the trades of the Colony whose existence is mainly dependent on that fiscal policy women and children are principally employed. Let the sum first named be divided by the 10,000 persons thus representing, chiefly, the labour of adult females and children directly indebted to protection for work, and the amount paid by the whole community for the support of this minority of workers called into existence by protection is reached. Each individual of this favoured number of protected workers, taken indiscriminately, represents $£ 66018 s$. $5 d$. annually extracted from the pockets of the taxpayers. This is surely a prodigious tax to pay for

1 Max Hirsch on Free Trade versus Protection in Australia. 
protected labour, and it is paid mostly by the working classes of Victoria for the illusive honour of providing inferior grades of employment for this insignificant, unproductive, and worse than superfluous contingent of labour, in order that a few manufacturers and importers may be enriched by the expenditure. To assume, however, that, but for protection, these nondescript workers would be doing nothing is absurd. There are thousands engaged in unprofitable local factory work in the Colony who would, by the introduction of free import trade, be transferred, in the interest of the Colony as well as to their own benefit, to more necessary and better wage-earning occupations, such as building trades, dairy farming, wine-growing, orchard-keeping, olive and tobacco cultivation, \&c. The wealth of the country is decreased by millions through the operation of protection in the manner just explained.

But it is by no means the rule that protection enriches the Colonial employer, his more frequent experience being that of ultimate loss and disappointment, if not of absolute failure. In 1873 the Victorian Legislature imposed a duty on imported woollen piece-goods of 10 per cent., under which four mills were started and paid dividends. There was an addition of 5 per cent. to the duty a few years afterwards and this brought about the ruin of the mills. The extra duty tempted fresh investors to embark in woollen manufactures. The four mills increased to nine. The trade was overdone. Several establishments either closed or went into liquidation, notwithstanding that the duty on woollen imports was raised from 15 to 20 per cent. Heedless of the lessons of experience, the cry arose from woollen manufacturers for still more protection against what was alleged to be competition with inferior woollen importations. The industry would be satisfied with nothing less than an increase of the import duty to 30 per cent., and to this astonishing proposal Mr. Gillies, when Premier and Treasurer a few years since, assented, although professing free-trade principles! This concession he made in the face of strong representations from apparel and slop-makers, who stated that so serious a restriction in their choice of materials as the increased duty involved would kill their trade. The Premier yielded to the demands of an industry employing only 734 hands, and ignored those proceeding from an industry employing 4,344 hands. Yet by the step he took the one industry was unfavourably affected without the position of the other being materially improved. It is an interesting commentary on the addition to the tariff by the Gillies Government that it very appreciably raised the cost of living, especially to persons earning small wages. The State Railway labourers sent a deputation to the Railway Commissioners to ask for an extra 6d.per day in consequence. The petitioners based their demand on the fact that the action of Parliament in increasing the tariff had compelled them to pay $3 s$. a week more than previously for the bare necessaries of life. They told the Commissioners that protective customs duties as they then stood filched from their slender wages, altogether, no less 
than $8 s$. per week or $£ 2016 s$. per annum. The police also demanded increased pay on account of the increased cost of living, and especially of clothing from the same cause. A leading Victorian farmer, not without reason, has publicly declared that 'if the taxes imposed by protection were levied openly and in a direct form in the Colony revolution and bloodshed would ensue.'1

Carriage-building, boot-making, the manufacture of machinery, furniture, and other branches of local trade are seriously injured in the same way and from similar causes. ${ }^{2}$ So truly does Mr. Goldwin Smith remark on the McKinley tariff : ' Protectionist legislators, indeed, have a tangled web to weave. . . . There is a natural antagonism between the protected manufacture and the protected producers of the raw materials of manufactures which it is impossible to conceal.' Despite the importunate calls for more and yet more protection for local industries still hopelessly struggling for independence in State leading-strings, the system fails alike to diminish imports which directly compete with protected goods and to increase the volume of locally manufactured exports.

We have a grave symptom of the unsoundness of the Victorian tariff in the fact that concurrently with the dangerous expansion of the imports of the Colony there is an equally unsatisfactory contraction of its exports. In the twenty-two years between 1868 and 1890, imports into Victoria in the former year, per head of the population, were $£ 201 s .9 d$, against $£ 2011 s$. $9 d$. in the latter year. The value of exported articles produced in Victoria in the same period gradually declined, and has not appreciably improved since. In 1868 the value of Victorian products exported was at the rate of $£ 1712 \mathrm{~s} .10 \mathrm{~d}$. per head, and in 1890 it was only $£ 94 s$. per head Yet the root-principle of protection, according to its votaries, is that in order to be prosperous a country should export more than it imports. ${ }^{3}$ The protectionist tariff system has aimed at building up the town at the expense of the country, although the latter is the chief and enduring source of national wealth. It tends to draw away the farming population from reproductive labour on the soil to populous centres in the hope of getting more highly-paid employment in factories. This hope, however, is too often doomed to disappointment, and the victims in many cases are seen at length drifting into the ranks of the unemployed, the wilfully indolent, and the vicious, who harry the Government periodically into borrowing excessively from England in order to provide them with employment on public works. Indeed it is not uncommon for Ministers to respond to the appeal of this motley crowd in the respect just alluded to as the price of securing their

1 The Melbourne Argus.

2 Hayter's Victorian Year-Book, under the head of 'Victorian Tariff, 1888-89,' vol. ii., and 1890-91, vol. ii.

3 In 1891-2 imports into Victoria receded, partly owing to investors refusing to lend more money to the Victorian Government, and partly owing to the depressed state of mercantile credit in the Colony. 
votes at the next parliamentary election under manhood suffrage. The wasteful expenditure of public loans indirectly resulting from the preponderance of power which protection puts in the hands of a class presents, at best, a wretched travesty of prosperity. Land in a protected Colony under the influence of large and frequent public loans encouraged by proletariate clamour acquires a fictitious value, and is cut up and built upon by speculators far beyond the actual wants of the population. The morbid excitement which thus results breeds in multitudes discontent with honest and sober occupation. In the general scramble for sudden wealth which follows, not a few are tempted to commit fraud. Reputations are blighted, and mercantile confidence gives place to general financial distrust. This is a literal description of what has lately occurred in Victoria. The evil has spread with more or less force to New South Wales and Queensland. But the oldest and strongest citadel of protection, as might be expected, has suffered most. While New South Wales continued loyal to free trade she showed a marked advance in all departments of productive industry compared with an opposite tendency apparent in Victoria. But unless protection is nipped in the bud in the parent Colony only a downgrade movement can be looked for, such as has already reversed the wheels of progress in Victoria. Under free trade in New South Wales employment was given to a much larger number than fill the ranks of labour in Victoria under so-called protective safeguards. One man settled on the soil requires two men to supply his manifold wants, and it stands to reason that extensive land, sheep, and cattle culture in a free-trade country must give employment to an immensely larger proportion of workers than can be employed in protected industries, in a country where these are artificially fostered by high tariffs to the neglect of farming pursuits. In the five years 1885-9 the population of Victoria, under protection, only increased at the rate of 16 per cent., while that of New South Wales, under free trade, increased at the rate of 32 per cent.

Trade restrictionists never cease to affirm that free trade tends to reduce wages to starvation point. It is one of their cant sayings that if protection were abolished the Colonial market would be flooded with the cheap products of foreign ' pauper labour,' and that wages, in consequence, would sink to the Chinese level. But if protectionist reasoning held good, the scale of remuneration to labour ought to be lower in New South Wales before the recent adoption of a protective tariff in that Colony than in Victoria. Reference to the tables of the Government Statist of Victoria, however, shows that average public salaries in Victoria are lower than they were in New South Wales as a free-trade Colony :

\begin{tabular}{|c|c|c|c|c|}
\hline & $\begin{array}{l}\text { Police. } \\
£ 145\end{array}$ & $\begin{array}{l}\text { Railways. } \\
. . £ 113\end{array}$ & $\begin{array}{l}\text { Post and } \\
\text { Telegraph. } \\
\ldots £ 113 .\end{array}$ & $\begin{array}{l}\text { Education } \\
\text { Departinent. } \\
\ldots £ 128 \text { per annum }\end{array}$ \\
\hline . & 182 & 134 & 134 & 121 \\
\hline
\end{tabular}

If our comparison be extended to rates of wages in general employments in Victoria, and we take the decade 1878-88, statistics exhibit

No. 10.- VOL. III 
striking results. Excluding domestic servants, out of 121 different industries fifty-eight are recorded in which no change of wages took place within that period. The alterations in wages in the other branches of labour, however, may be.classified as follows :-

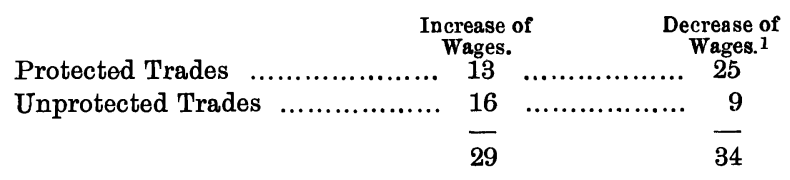

Hence in the ten years wages fell in thirty-four trades, mainly comprising those which are protected, despite the terrorism of strikes which Trades Unionism has put in operation to raise the scale of remuneration. It may also be stated that under the fiscal system, which is credited with being specially framed to protect the interests of the labouring classes of Victoria there is a large army of workers who either work in their own houses or in those of sweaters; and, after toiling from twelve to fourteen hours per day, many of these do not earn more than a miserable pittance of $1 s$. $6 d$. to $2 s$. $0 d$. per day, their average pay being about $1 \frac{1}{2} d$. per hour. Putting forth their utmost effort they are rarely able to earn more than 15s. per week of seventy-two hours which in a country of high cost of living and reduced purchasing power of wages like Victoria does not represent in value two-thirds of the same amount in England. It is a poor tribute to the intelligence and self-reliance of any people in presence of such economic abuses specially rife among a section of the working classes in a Colony claiming as the glory of its fiscal system that it guards, above all things, the welfare of labour, that working men should allow themselves to be persistently hoodwinked by demagogues, in as well as out of the Government, who are ignorant of the simplest elements of political economy. These stump politicians go on piling up duties as a panacea for all the ills of labour, although it must be obvious to every reflecting person that the very advantages falsely promised by protection recede from view as the import tariff increases.

Protectionist empirics are constantly offering the example of the United States for the imitation of Victoria, apparently forgetful of the fact that the great Republic advances in population, manufactures, commerce, and wealth in spite of past fiscal extravagances and not in consequence of them. Besides, there can be no means of comparing a single Colony having a population of little more than a million,- which erects protective barriers against all other Australasian Colonies-with a country having a population of $65,000,000$ spread over forty States and Territories which are practically governed by free-trade principles

1 A St. Louis journal states that the immediate effect of the McKinley tariff in the United States was to reduce the wages of millions of workmen from 5 to 20 per cent. taking the purchasing power of the paper dollar as a test of value. 
in their mercantile relations with each other. Intelligent Americans themselves keenly appreciate the untrammelled free-trade connection which binds the States together, and smile at the ridiculous spectacle of one or two small Australasian Colonies in close proximity to each other carrying on an exhausting tariff war against each other. Similarly, the 5,000,000 of people inhabiting the several provinces of the Canadian Dominion are all unfettered in their trade relations with each other from the Atlantic to the Pacific and from the Arctic Sea to the United States border.

At a late meeting of Victorian farmers hostile to the prevailing customs tariff the chairman, speaking for many of his class who had become convinced of the false character of the prospects which protection holds out to them, said that ' to encourage artisans employed in making engines and carriages, instead of encouraging the farmers to raise natural products wherewith to purchase such articles, is to waste the money represented by the extra cost as completely as if it were thrown into Hobson's Bay.'

Matthew Macfie

\section{The Homestead Strike.}

Honestead is a town of some 10,000 inhabitants on the banks of the Alleghany River, a few miles above the city of Pittsburg. Although politically an independent borough, it is virtually a suburb of Pittsburg, and is a part of the great iron manufacturing region of which that city is the centre. It has been built up within the last ten years. In 1880 the population was less than a thousand; in 1890 it was nearly 8,000; in 1892 it was between 11,000 and 12,000.

The rapid growth of Homestead was caused by the development of the Carnegie Steel Works at this point. The Steel Company is a. limited partnership, manufacturing iron and steel, not only at Homestead, but at a number of other places in and about the city of Pittsburg. The total number of persons employed by the Company is stated to have been some 13,000. At Homestead itself, some 3,800 men were employed; and the population of the town consisted almost exclusively of the workmen in the steel works, and the tradesmen who purveyed food, drink, and lodging to them. The business at Homestead is chiefly the manufacture of steel structural materials, used largely in fire-proof buildings. At the time of the great strike the Company was also engaged in making armour plate, under contract with the United States Government, for vessels of the navy. The Carnegie Company has taken a very large part in the extraordinary development of the iron and steel industry in the United States in the last ten years, and the facts just stated indicate how enormous is the scale upon which its operations are conducted.

The chairman of the Company, and its manager during the strike, 